Danijel Čorak ${ }^{1}$

Ivica Šnajder ${ }^{2}$

\title{
MARKETING STRATEGIES AND THEIR APPLICATION IN SMALL AND MEDIUM ENTERPRISES EMPHASIZING THE MODERN METHODS
}

\section{Abstract:}

This paper will be focused on marketing strategies and their application in SMEs. Application of marketing today has become almost mandatory and the need for implementation of a common strategy. The marketing elements and strategies to invest more and more and business and other entities allocate an increasing proportion of its funds administration with a view to later less uncertain business. Marketing and its strategy is possible, and should be implemented in almost any aspect of a subject. If it does not comply with the above instruction, often in question leads itself existence same entity because who does not progress, ie. who is stagnating, in fact, going backwards, because the competition is not standing still.
The competition is more ruthless, especially nowadays. The reason for this is the increasing power of buyers or consumers who have an increasing role in defining a product or service. One of the reasons is also the opening of borders, cheaper transportation, labor costs, etc. All of this points to the need for separation from dozens of new ideas, products, services, etc. Any strategy including the implementation of the marketing strategy should be preceded by thorough market research and situation in general. A number of entities, institutions and others neglect this very important step because of unwarranted fear of spending scarce resources, which actually unwittingly placed in a even worse situation, implementing some strategies which later often results in failure and even higher additional costs.

\section{Keywords:}

marketing strategies, small and medium enterprises, implementation

\section{Author's data:}

${ }^{1}$ Danijel, Čorak, univ. spec.oec., PhD candidate, Ekonomski fakultet u Osijeku, Danijel d.o.o., (Director), E. Podubskog 59, 34310 Pleternica, corak.danijel@gmail.com 2|vica, Šnajder, mr.sc., Senior lecturer, Veleučilište u Požegi, Vukovarska 17, Požega, isnajder@vup.hr 


\section{Introduction}

There are many marketing strategies and methods of application thereof, and in this paper will be discussed about the strategies that can be easily implemented in an environment of Republic of Croatia and the business opportunities created by the same rule. Already widely known more or less used resources are guaranteed, tourism, production of all shapes and feed primarily due to the favorable geological position and climatic preconditions, industries and others. This paper will cover only some of the strategy and will briefly explain the advantages, disadvantages, route of administration and others. Požžško-slavonska County also has a number of untapped potential. Some of the main reasons for not using them are usually lack of will, ignorance, political and other interests, lack of experts, and all the above is often a continuation of past "outdated" attitudes and manner of subjects and management of the entire industries. In these areas there is a high possibility of using digital marketing, which, as we shall see in the work of a contemporary form that can certainly contribute to the benefit of those who use it, ie. Implemented in your business entity, and other. Life nowadays has become unthinkable without the Internet. In some moments we are not aware that we are "connected" to the network and access the Internet as normal as the availability of some key elements in life ie. the factors necessary in life and for the very existence. The globalization of the world also contributes to the universal "Internetization" and search links in all spheres of life. There are many features and benefits of the Internet and, as already mentioned, most people today take it "for granted", ie. become our everyday life, but we arenot even aware of. If you look in the past or not-so-distant past, the world has changed in terms of technology and changing rapidly, which they themselves can not conceive, and had need on a daily basis to be adjusted but also take into account the negative sides of the same.

\section{Internet marketing}

Internet marketing and Internet advertising, more and abbreviated as i-marketing, web marketing, online marketing, or eMarketing, is advertising of products and services via the Internet. [7]

In order to achieve a successful online campaign, people in charge of the implementation of Internet marketing must follow new trends in information technology and trends in the habits and preferences of consumers. Internet marketing or advertising over the Internet has several advantages over traditional forms of marketing. The key advantage of this type of marketing is a low cost, measurability and precise targeting specific groups of people. Every day, the advertising can be traced and thus collect visitor statistics Website and customer specific products and services. These data are collected in databases and also gets the ability to obtain the desired information at any time. This method enables better decision-making and it is evident how the individual investment worthwhile. At any time, it is possible to stop the campaigns that do not generate a satisfactory return and start a new campaign, which is expected a better result.

The campaign over the Internet can be run for several hours, and the results are visible almost immediately. The share of these online campaigns in the world are growing more and more, and in some countries such as the United Kingdom's Internet surpasses advertising on television. Campaigns over the Internet lately is increasingly being implemented by Google AdWords. Adwords is one of Google's most cost-effective services. An example is the 2009 year in which Google through advertising via AdWords revenue of $\$ 23$ billion. AdWords offers PayPer-Click (PPC) advertising, targeted web advertising, banners and other means of advertising. Turns out our local, national and international distribution. Listing on Google is a short text consisting of one-line headline and two 
lines of text. Advertisements can also be a picture but must comply with standard parameters defined by the Interactive Advertising Bureau (IAB). Many businesses have recognized the importance of Google ads and so created a huge demand for the service. To be able to meet this demand requires advanced technical support and engineering. PayPer-Click (PPC) is a system through which Google charges visits some sites that I asked for service and an ad. The person who gives ad choose words that best describe their business and choose the highest price you want to pay. Name Pay Per Click (pay per click) is used, because it is actually working principle of this advertising. Owner Pay Per Click [pay per clickl ads pay the agreed sum of money every time a person clicks on an ad that leads directly to your web site [8]. A person can clearly define which area will Google search engine users see the ad. Can be determined speaking countries, state, city, time and other parameters and thus pinpoint the target group that a firm is important. After placing ads Google AdWords offers a variety of statistical tools to monitor the use of our site related to the ad. The offer is possible at any time to change or delete and to stop cost.

\section{Internet marketing plan}

As well as marketing plan, internet marketing plan is a detailed description of the objectives and procedures with which it's possible to achieve the realization of one or more marketing objectives. Marketing plan is drawn up to increase business efficiency. It is necessary to make a plan before introducing a new product, the brand or the introduction of new product lines. In the same way, and Internet marketing plan increases the chances of success in the implementation of business decisions. Internet marketing plan does not use the traditional media but concentrates on conveying marketing messages over the Internet. Marketing plan usually refers to a period of one to five years and belongs to the entire business plan. Internet marketing plan should be part of any marketing plan because it uses the media that is available to many people. Today, more and more people use the Internet, which is developing faster and faster. The rapid development and easy Internet access are enabled by information technology.

E-marketing plan is a plan for the formulation and implementation of e-marketing. It is a dynamic document routing, linking the company's business strategy (models of $\mathrm{e}$ commerce) with marketing strategies. Companies usually drawn up annual plans, Iong-term plans and strategic plans . In fact, the e-marketing plan does not differ from offline planning and includes analysis, planning, implementation and control, and applies to all Ievels of planning [4].

\section{Information technology}

With the development of information technology (IT) communication costs it's decreased and so it is now possible to exchange information in seconds from anywhere in the world that is connected to the Internet network. Internet is a medium that can not be ignored because it allows direct communication with a large number of customers and potential customers. This medium allows easy measurement of success and based on the collected statistical data facilitated investment decisions marketing efforts in certain groups, sectors, geographical areas and more. Information era is the fastest growing social phenomenon. The progress of this phenomenon in particular contributed to the website on which the wider difference of opinion attitudes and other information. A successful website must be useful for the person who opened it and allow the user to meet their needs and desires related to a particular topic. The key concept of information technology is to connect. A huge role in connecting different websites and their users have a search engine. When 
comparing the performance of different media came to the conclusion that the 50 million users Radio took 38 years, television 13 years, the Internet 4, IPod 3 , and Facebook only two years. From the comparison it's shown that the less time people need to get used to the new media, and marketing of individual companies must take the opportunity to find customers who need to meet specific wishes and needs. This led to the development of Internet marketing.

One of the most common reasons for business failure of firms, particularly those in the field of electronic commerce vaguely defined objectives. Declaration goals must be clear, measurable and time-determined. Companies perceive great potential of e-commerce and immediately rush to use e-tools without are unambiguously define your goals and clearly defined strategy [4].

\section{Creating an Internet Marketing Plan}

Before the Internet Marketing you need to know the potential customers who might be interested in specific products, services and ideas. When the company is sure that he wants to use Internet marketing it's necessary to make a detailed plan of such marketing. People who draw up a plan and that are responsible for the implementation of Internet marketing have certain knowledge. They have to know the characteristics and mode of implementation of the classic marketing that is done over " old " media. In this release include: radio, television, posters and other similar media. In addition to knowledge of marketing to people who implement and draw up such plan is necessary and II educated. They need to know basic computer concepts and how to conduct the campaign planned actions via the computer. It also requires an understanding of statistical concepts in order to monitor the success of the campaign. Today a lot of programs and tools facilitate the planning and implementation of internet marketing but are placed great demands and it is a great responsibility to the people who are in charge of the job. There are special seminars where employees learn how to plan and implement Internet marketing. Such seminars usually charged and last from several hours to several days. Examples of seminars held on the topic of Internet marketing can be found in every major city. For example, these seminars are held in Osijek in HUP (Croatian Employers' Association).

For its business CEA says: "With all my activities emphasize the importance of the social role of employers, and maximum efforts are trying to influence events in the region, in order to be more adaptive needs of the economy ". It is important to raise awareness of the need to properly escorted internet marketing. Creating an Internet Marketing Plan and its implementation can be internal and external. Internal means that Internet marketing plan and its realization conducted by employees of the company. Their goal is to improve business expenses. The cost of Internet marketing are relatively low in relation to the availability and effects of realisation. For this type of marketing you definitely need a good education and skills of employees in order to increase chances of a successful Internet marketing campaign. The experience gained from the past, but conducted campaigns to better plan their future. When a person have more experience, he or she can better assess potential problems so they plan before they occur in practice. Some of the useful tools for independent creation of internet marketing plan are: ad serving, media planning, Doubleclick Ad Planner and others. Internet marketing plan can be carried out externally. External implementation of Internet marketing plan is 'outsourcing'. The benefits of the services of another company that offers a compilation of Internet marketing plan and its implementation. Before the " outsourcing " was the only way to reduce costs. 'In the meantime, the 
practice of outsourcing has developed and is today the selection of management and opens the way to increase efficiency and value added [9].

It is possible that at first glance externally making Internet marketing plan seems expensive but it is important to look at all the cost perspective. Thus, the more likely errors in the internal implementation than external. This can be explained by the amount of experience that employees are costly for business.

\section{Summary}

2. Web analysis market statistics

3. Creating a web marketing strategy communication

4. Planning the necessary funds for web marketing

5. The creation of the marketing team
Setting objectives for Internet marketing, and specifying the objectives of your promotions on the Internet.

In order to reach these data it is necessary to find or commission research that will lead to real data on the state of the market, including the Internet market.

Planning and strictly determine the optimal web strategy in accordance with the established objectives and the state of the markets.

determination of specific segments of implementation of web marketing strategy. Planning prices, research, analysis, creation of special studies, promotional material, etc.

Functions in the team determine who will perform marketing tasks and how. The organization of human resources here is an extremely important part in creating a successful business, including in the implementation of Internet marketing plan ie. Web marketing plan. All of the above is the case for the creation of such a team in your company.

6. Creating a corporate identity Classic elements of web marketing strategies include the peculiarities of the Internet (mission, logo, etc.).

7. Determination of Time Limits

8. Designing promotional campaigns

9. Creating additional (bonus) marketing materials and campaigns

10. Translation of own market research

11. The implementation of promotional programs

12. Measurement results of marketing activities
The organization of marketing activities without the precise dates, can jeopardize the entire internet marketing plan. Creating conditions for effective designing individual internet marketing campaign.

The guidelines, descriptions of individual steps in the performance of web marketing campaigns, the integration of the necessary documentation, preparation of special materials, planning presence at trade shows, conferences, media or monetary sponsorship, presenting at seminars.

By using their own resources (websites, mailing lists, surveys, etc. to create the notion of a particularities of users of Internet services / Web services target company (or your competition). Based on the prepared segments internet / web marketing plan implemented specific marketing campaign.

The exact data that enable very precise determination of the following marketing campaigns and correction mode presence Web companies on the online market and the market in general.

Table 1. Internet Marketing Plan, source: http://www. marketing-odjel.com/web_marketing_plan, 10.04.2016. 


\section{E-marketing and marketing information systems (MIS)}

The electronic marketing (e-marketing, telemarketing, online marketing) is a way of achieving market-oriented activities of the company with intensive use of information and communication (Internet] technology. These two technologies, and their synthesis, are applicable in the realization of all marketing functions important from the point of business small business owners, such as: Notification of market, Market research, Advertising and public advertising. The use of
Internet technology causes the realization of these marketing functions in a manner significantly different from that practiced in the framework of traditional marketing [3].

The marketing research on the Internet are standardized procedures of application of scientific methods in the process of collecting, registering, processing, analysis and interpretation of data within the Internet environment, which again used for making marketing decisions.

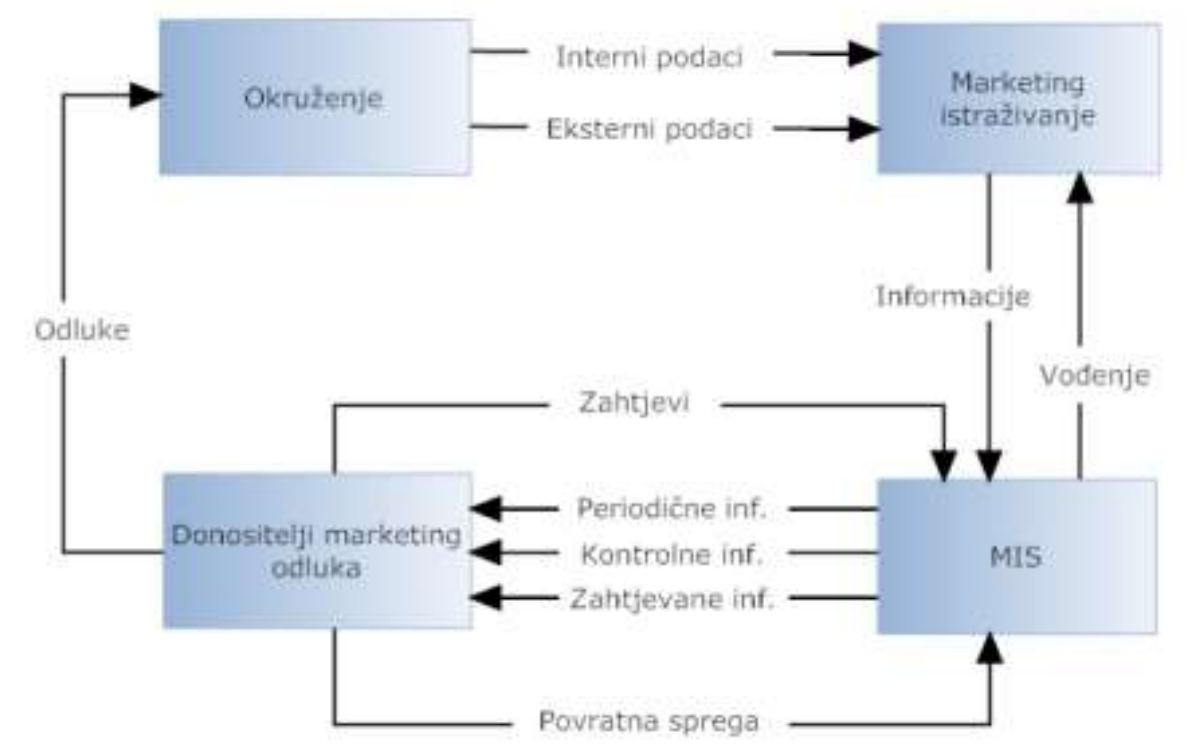

Figure 1. MIS us. eMIS, source: http://oliver.efos.hr/nastavnici/druzic/dokumenti/emktg200g/sppemarketing2010-05-eMIS.pdf, 26.06.2015.

\section{E-marketing techniques}

Online technologies enable a number of techniques primarily aimed at the promotion and advertising, which resulted in a number of new terms and promotional techniques described as the technique of e-marketing. This is usually referred to the following terms:

- Viral marketing;

- Affiliate marketing;

- Permission Marketing;
- Referral marketing;

- One-to-One Marketing;

- E-mail marketing;

- Frequency marketing;

- Real-time marketing;

- Content Marketing [8]

"Viral" marketing is used to emphasize the detail techniques used to spread marketing messages. Affiliate ie. associated or affiliated with marketing indicates the advertising technique that 
works so that the owners of small Web sites placed links, banners, etc., on their own website and thus get paid for driving sales. Marketing techniques refferal marketing is considered one of the most successful and most effective ways of promoting a basic goal is to actually across the users themselves, visitors and other increases attendance, sales and profits. One reason for the success of this technique is that the site itself, the product, manufacturing or sales program and others. Not recommended by the subject itself, but from other users who have the same positive experience. This fact instills greater confidence to new customers and thus their response more. Content marketing ie. marketing content aims to provide quality, relevant and valuable information which in turn are intended to lead to profitable user actions.

\section{Advantages and Disadvantages of $\mathrm{E}$ - commerce}

Electronic commerce its exponential growth and great popularity to numerous advantages over conventional methods of trading. The advantages of electronic commerce offers can be divided into:

- Benefits for vendors,

- Benefits for consumers.

Advantages for one and the other categories are Iargely related. For example, if traders cut costs they are able to reduce the cost. Using improved marketing merchants create competitive advantage, and customers receive better products [5].

It is widely known that the number of companies that appear on the Internet continues to increase, and some of the benefits that help them in making decisions about participating in the Internet market are:

\section{- $\quad$ Expanding market}

- $\quad$ The size of the sales program

- Improved marketing

- Cost reduction

- Longer working hours and others.

As mentioned above, there are numerous benefits of Internet commerce and the consumers themselves, and some of them are:

- Better information

- A larger variety of products

- $\quad$ Flexibility the personalization of e-shops and the like.J

- $\quad$ Convenience (buying from the comfort of their own homes and the like.]

- $\quad$ Lower prices and others. [4]

There is no electronic commerce is not without its difficulties. Some of these difficulties have caused themselves traders mismanagement affairs, some created by the state and its laws, and the others are inseparable companion of electronic commerce. However, the impression is that all the problems solved because many institutions have given priority to electronic commerce as a main driver of the economy in the future. [3]

- Some of the difficulties that arise in electronic commerce are:

- Too fast changing technology Irequires specialization]

- The lack of marketing concepts (nonimplementation of basic marketing rules]

- Legislation Idiversity of laws between countries]

- International difficulties llinguistic and cultural differences]

- The digital divide llack of Internet connection in all households - the last time the digital divide drastically reduced]

- $\quad$ The inconvenience of the product (because of the size and the like) and others. 
In addition to Pay-Per-Click ads Google and other search engines, allows users to quickly find sites that interest them. How could a company that had a better positioning in the results, must in your website targeted to enter items to which they will be search engines to recognize. The developers of each search engine listings criteria by which it seeks website. The aim is that the user as soon as he found What he was looking for. A better result in the positioning of a website can be achieved by SEO [search engine optimization] optimization.

'Search Engine Optimization (known as SEO) and website optimization for search engines or search engines is part of Internet marketing that deals with the positioning of websites on search engines for the keywords that best match the content of the page. The goal of optimization is to increase targeted visits to web sites with search engines and thus increases the number of contacts or direct sales. World statistics and studies have shown that nearly $90 \%$ of all visitors to the average website is coming from the search engines [10].

It is necessary to consider a lot of factors that affect the successful SEO optimization. In many companies the process of compiling SEO optimization comprises the following steps: Research the competition and the market, research and application of keywords [keyword], optimising the site (on-page SEO), structuring website and internal links, successful link building, monitoring results and optimize results. SEC optimization can be on-site and off-site. SEO On-site optimization means that the page add keywords to help search engines recognize the content of the website and offer them to the user. SEO Off-site optimization does not include the keywords on the page than links with ostailm sites with similar content and other links that can take users to the exact content of that which is sought. Well coordinated combination of on-site and off-site SEO optimization improves the positioning in the results and further reduce their Pay-Per-Click. So, a combination of different methods and tools as well as to able to achieve optimum availability of the site and our lead over the competition.

\section{Techniques and means of advertising on the Internet}

In principle, we should distinguish advertising web site (page) of the advertising of certain products or services on the Web, although it is sometimes difficult to distinguish. The World Wide Web is an excellent ad option, however the web site should be supported to become successful comparing to competitors and to get the attention of visitors. Web is comparable to the endless street full of shops which is an extremely important customer to supply the exact address specific trade, because otherwise the customer will not find [4].

There are many online ways to promote someones web, for example, banners, sponsor relations, editor comments, links and many others. It is impossible to make a distribution that would apply for more than a few days, but for this very reason the division is not limited to a certain number. One advertising techniques that lately quite often used on the Internet and in other media and product placement. Surreptitious advertising can be defined as a form of advertising in which a particular product or service represents an integral part of any content that is presented to the audience. Refers to the presentation of products or services with the aim of by the audience perceived as quite normal part of what the public consumes, and seeks to show that 
less noticeable, and yet with it greater influence on consumers.

An example of this method of advertising are displaying images, videos, etc., multimedia content, containing at a glance "invisible" ad for a brand, product and so on. This form of advertising can occur "by accident", with financial compensation by the seller or however, without any financial compensation. Same division and ways of advertising are dynamic processes, and they sometimes experienced marketers or expert in the IT sector is very difficult to monitor.

\section{Conclusion}

Philip Kotler, one of the most respected authority theory and practice of marketing, under the management marketing involves social and business processes through which individuals and / or groups come to what they need and what they want. $\$ 0$, marketing is a continuous process of planning and executing the conception of ideas, goods or services, determining their price, promotion and distribution, which creates the exchange, satisfying both individual and organizational change. [4]

The implementation of marketing on the Internet environment today means an advantage over the competition and gain the trust of the broader aspects of the customers. Marketing is certainly in itself plays a major role in the life cycle of any company, be it manufacturing, sales and service. Entities in the economy is often due to lack of financial means "forget" that they neglect marketing which ultimately can often lead to the deterioration of the same subject, because regardless of the quality of the product or service offered, if the potential buyer is not aware of the offer and quality to sales process will not come . As in any other market, and to the "global" -Internet market there is a need for marketing ie. advertising activities without which the same market could not Iong survive. So we can say how the man without the possibility of connecting to the Internet today is as a man who don't have some of the key factors for life. It has become unthinkable to be without "connections" while driving the bus, during a picnic in the countryside, during lectures at universities. citing the negative side internalisation, we can conclude that the Internet enables "parallel lives", that the real is imposed to the virtual.

Some of the problems that appeared in the research and writing of this paper are certainly factors limiting the number of participants, ie. Research on the quality of the sample. There is still insufficient awareness of the respondents about the use of computer programs and applications that help in conducting research is also a problem in quality circles the research. Small communities in which we live, with consequently a lack of knowledge in the filed of information and is one of the reasons the previous occurrence of problems in the implementation of the very research in general.

As the basic differences and conclusions related to the required solutions and the very results of the research concluded that they need to work on the education of young professionals or those older marketing and its importance. Implement something in the system is most easily-showing success stories and examples from real life, not insisting solely on theory, which often does not apply in full, all depending on the environment and circumstances. If the people who are responsible in some businesses in a quality way to present the features and benefits "marketing" mindset, before they are placed very strong tool that will help them if 
they implement it in the right way greatly help grow the company. The research results have been somewhat disappointing and, because of delays in the modern business world, but not unattainable and can be quickly corrected by the above methods and proposals.

Nowadays, it is practically possible do not leave the house for some food, pay bills, buy furniture, clothes, hang out with friends, use internet banking etc. All the above perhaps can be done even "better" over the network, but as much as previously mentioned sound negative, I think it does have a much more positive factors that help us in life, to overcome various obstacles and in many other ways. The time and amount and type of changes that also yields have become key factors that influence the survival of subjects in the global market, and he certainly must learn, if you do not want to be, "stuck in time."

\section{References}

[1] Meler, M.: Istraživanje tř̌išta, Sveučilište J.J. Strossmayera u Osijeku, Ekonomski fakultet u Osijeku, Osijek 2005.

[2] Meler, M.: Osnove marketinga, Sveučilište J.J. Strossmayera u Osijeku, Ekonomski fakultet u Osijeku, Osijek 2005.

[3] Panian, Ž.: Internet i malo poduzetništvo, Informator, Zagreb, 2000.

[4] Ružič, D., Biloš, A., Turkalj, D.: e-Marketing, 3. izmijenjeno i prošireno izdanje, Sveučilište J.J. Strossmayera u Osijeku, Ekonomski fakultet u Osijeku, Osijek, 2014.

[5] Ružicic, D., Tomčic, L., Turkalj, Ž.: Razmjenski odnosi u marketingu, organizacija i provedba, Sveučilište J.J. Strossmavera u Osijeku, Osijek, 2002.
[6] Segetlija, Z: Irgovinsko poslovanje, Sveučilište J.J. Strossmayera u Osijeku, Ekonomski fakutet u Osijeku, Osijek 2006.

[7]

http://hr.wikipedia.org/wiki/Internet_marketing, 26.04.2016.

[8] http://www.internetsvijet.com/pay-per-clickplati-po-kliku-nacin-oglasavanja/, 26.04.2016.

[9]

https://www.cee.siemens.com/web/croatia/hr/cs b/it-solutions/rjesenja/Pages/outsourcing.aspx, 26.04.2016.

[10] http://www.webstrategija.com/03/sto-je-toseo, 26.04.2016. 